\title{
Pengaruh Kecerdasan Intelektual, Kecerdasan Emosional, Kecerdasan Spiritual, dan Faktor Situasional Pada Keputusan Etis Konsultan Pajak
}

\author{
Ni Wayan Muliartini1 \\ Fakultas Ekonomi dan Bisnis \\ Universitas Udayana, Indonesia. \\ Email: muliartini9@gmail.com
}

\author{
I Ketut Jati ${ }^{2}$ \\ Fakultas Ekonomi dan Bisnis \\ Universitas Udayana, Indonesia.
}

\begin{abstract}
ABSTRAK
Tujuan penelitian ini adalah untuk memperoleh bukti empiris bagaimana pengaruh kecerdasan intelektual, kecerdasan emosional, kecerdasan spiritual, dan faktor situasional pada keputusan etis konsultan pajak di Daerah Bali. Jumlah sampel yang digunakan sebanyak 79 responden pada 69 kantor konsultan pajak di Daerah Bali dengan teknik penentuan sampel purposive sampling yaitu konsultan pajak yang menangani klien dan tidak dibatasi jabatan serta memiliki sertifikat brevet USKP. Pengumpulan data dilakukan dengan metode kuesioner. Teknik analisis data yang digunakan untuk menguji hipotesisi dalam penelitian ini adalah Analisis Regresi Berganda. Berdasarkan hasil penelitian yang dilakukan diketahui bahwa kecerdasan intelektual, kecerdasan emosional, kecerdasan spiritual berpengaruh positif pada keputusan etis konsultan pajak. Hubungan profesional berpengaruh negatif pada keputusan etis konsultan pajak, namun preferensi risiko dan kekinian informasi tidak berpengaruh signifikan pada keputusan etis konsultan pajak.
Kata Kunci : Kecerdasan Intelektual, Kecerdasan Emosional, Kecerdasan Spiritual, Preferensi Risiko.

The Influence of Intellectual Intelligence, Emotional
Intelligence, Spiritual Intelligence, and Situational
Factors on Ethical Decisions of Tax Consultants

\begin{abstract}
The purpose of this study was to obtain empirical evidence on how the influence of intellectual intelligence, emotional intelligence, spiritual intelligence, and situational factors on the ethical decisions of tax consultants in Bali. The number of samples are 79 respondents at 69 tax consultant offices in Bali with purposive sampling technique, Tax consultant who handles clients and unlimited positions and has USKP certificate. Data collection is done by questionnaire method. The analysis technique used in the research is multiple regression analysis. The results shows that intellectual intelligence, emotional intelligence, spiritual intelligence has positive effect on the ethical decisions of tax consultants. Professional relations had a negative effect on tax consultant ethical decisions, but risk preferences and information current did not significantly influence the tax consultant's ethical decisions.
\end{abstract}

Keywords: Intellectual Intelligence, Emotional Intelligence,

\footnotetext{
Spiritual Intelligence, Risk Preference.
}

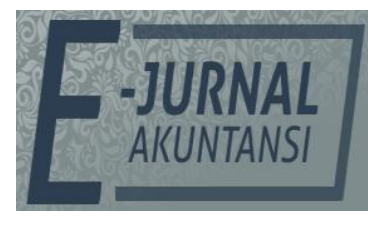

E-JA

e-Jurnal Akuntansi e-ISSN 2302-8556

Denpasar,

Vol. 28 No. 3

September 2019

Hal. 1866-1885

Artikel masuk:

12 Juni 2019

Tanggal diterima:

09 Agustus 2019 


\section{PENDAHULUAN}

Pajak merupakan iuran wajib bagi orang pribadi atau badan ke kas Negara berdasarkan undang-undang yang bersifat memaksa dan tidak mendapatkan imbalan secara langsung untuk kepentingan negara (Undang-Undang No. 16 tahun 2009 tentang ketentuan umum dan tata cara perpajakan). Sistem pemungutan pajak yang berlaku di Indonesia saat ini adalah self assessment system, yaitu sistem pemungutan pajak yang memberikan kepercayaan bagi wajib pajak untuk menghitung dan melaporkan sendiri kewajiban perpajakannya. Akan tetapi peraturan pajak yang semakin rumit dan selalu mengalami perubahan dari waktu ke waktu membuat wajib pajak mengalami kesulitan dalam mengikuti perkembangannya. Hal tersebut membuat jasa konsultan pajak semakin berperan dalam memfasilitasi wajib pajak untuk melakukan kewajiban perpajakan. Definisi konsultan pajak menurut Peraturan Menteri Keuangan Republik Indonesia Nomor 111/PMK.03/2014 tentang Konsultan Pajak adalah orang yang memberikan jasa konsultasi perpajakan kepada wajib pajak dalam rangka melaksanakan hak dan memenuhi kewajiban perpajakannya sesuai dengan peraturan perundang-undangan perpajakan.

Hal ini didukung oleh Pratama \& Wirama (2018) yang menyatakan bahwa konsultan pajak memiliki peran dalam memastikan pelaporan perpajakan yang dilaporkan oleh kliennya telah benar dan sesuai dengan peraturan perundangundangan yang berlaku. Undang-Undang Perpajakan terkadang di dalamnya terdapat daerah abu-abu atau hukum yang tidak jelas, disanalah peran konsultan pajak untuk membantu pemerintah dalam meningkatkan kesadaran akan kepatuhan perpajakan bagi wajib pajak. Konsultan pajak dapat membantu wajib pajak untuk mengefisiensikan jumlah pembayaran pajak, mengurus administrasi pembayaran pajak, hingga menyelesaikan sengketa perpajakan antara WP dan fiskus sebagai kuasa WP (Kusuma et al, 2016). Fasilitas jasa yang diberikan oleh konsultan pajak membuat permintaan akan jasa konsultan pajak semakin diminati, terutama dalam mengefisiensikan jumlah pembayaran pajak (Adriana, 2013). Pernyataan tersebut sependapat dengan Devos (2012) yang menyatakan wajib pajak menggunakan jasa konsultan pajak untuk mewakilinya dengan sejumlah alasan, yaitu keinginan untuk melaporkan surat pemberitahuan tahunan (SPT) yang akurat terutama karena kurangnya pengetahuan pajak. Berdasarkan kompleksitas hukum pajak saat ini, keinginan untuk meminimalkan pajak mereka yang diwajibkan untuk dibayar, ketakutan mereka akan membuat kesalahan dan dikenai sanksi, atau hanya karena kurangnya waktu untuk menyelesaikannya.

Wajib pajak memahami bahwa pengetahuan dan wawasan yang dimiliki oleh konsultan pajak dapat memfasilitasi wajib pajak dalam memenuhi kewajiban pajaknya dengan jumlah yang seminimal mungkin (Budileksmana, 2001). Hal tersebut seringkali membuat konsultan pajak dihadapkan oleh isu yang melibatkan pengambilan keputusan etis, karena sesungguhnya tugas seorang konsultan pajak bukan untuk berhadapan dengan pemerintah untuk membela kliennya, tetapi konsultan pajak memiliki peran untuk membantu masyarakat dalam memenuhi kewajiban perpajakan dengan benar sesuai dengan peraturan perpajakan yang berlaku (Sutanto \& Tjondro, 2013). Pernyataan tersebut sependapat dengan Blanthorne et al. (2005) yang menyebutkan isu yang 
melibatkan pengambilan keputusan etis konsultan pajak terjadi karena adanya dual agency antara hubungan konsultan pajak dengan kliennya. Konsultan pajak di satu sisi wajib membina hubungan yang baik dengan kliennya namun di sisi lain konsultan pajak wajib mematuhi peraturan perundang-undangan yang berlaku. Konsultan pajak yang menghadapi situasi tersebut harus berpegang teguh pada kode etik profesinya agar bisa mengambil keputusan secara etis.

Suatu keputusan bisa dikatakan etis apabila keputusan tersebut merupakan keputusan yang baik secara legal maupun moral dapat diterima oleh masyarakat luas (Trevino, 1986). Konsultan pajak yang menjalankan profesinya sering kali dihadapkan oleh dilema etis, sehingga dia dituntut untuk selalu bisa mengambil keputusan yang etis agar tidak merugikan pihak manapun. Hal ini sesuai dengan pendapat Harmana et al. (2017) yang menyebutkan konsultan pajak akan membuat keputusan yang bertentangan dengan prinsip-prinsip profesionalismenya ketika ia menerima imbalan ekonomis atau mendapatkan tekanan yang menyebabkan terjadinya dilema. Pasal 28 dan 29 Peraturan Menteri Keuangan Nomor 111/PMK.03/2014 tentang Konsultan Pajak memberikan pengawasan yang sangat ketat bagi para konsultan pajak. Seorang konsultan pajak jika menangani suatu wajib pajak, dan pada akhirnya wajib pajak tersebut mengalami sengketa dan bahkan menjadi tersangka dalam tindak pidana perpajakan, maka ijin operasional konsultan pajak yang bersangkutan akan dibekukan dan bahkan dicabut.

Contoh kasus keterlibatan konsultan pajak dalam pelanggaran etika adalah keterlibatan konsultan pajak Robertus Santonius dalam membantu wajib pajak yang ditanganinya untuk melakukan kecurangan. Kecurangan tersebut terungkap dalam kasus Gayus Tambunan. Jaksa menilai Robertus telah menyuap pegawai negeri, dalam hal ini Gayus Halomoan Tambunan untuk memenangkan perkara banding PPN PT Metropolitan Retailmart di Pengadilan Pajak. Putusan pengadilan banding PPN 2006 dan banding PPN tahun 2007 setelah dimenangkan, Robertus memberikan uang kepada Gayus sebesar Rp. 925 juta (Berita Satu, 2011). Kasus lainnya terungkap dalam kasus Hendro Tirtawijaya yang merupakan konsultan pajak dari PT Ditax Management Resolusindo yang ditahan oleh tim penyidik tindak pidana khusus kejasaan Agung sebagai tersangka baru kasus dugaan korupsi pajak dan pencucian uang mantan pegawai Dirjen Pajak bernama Dhana Widyamika. Hendro diduga sebagai makelar dalam mengurus masalah pajak PT Mutiara Virgo yang menerima uang sebesar Rp. 20,8 miliar dari Direktur Utama bernama Johny Basuki untuk diserahkan ke Herly Isdiharsono yang merupakan atasan Dhana dan merupakan rekanan Hendri di Kantor Pelayanan Pajak PT Mutiara Virgo (Saptohutomo, 2013).

Robertus dan Hendro Tirtawijaya telah melanggar Kode Etik Konsultan Pajak, yaitu tidak patuh pada hukum dan peraturan perpajakan, serta tidak menjunjung tinggi integritas, martabat dan kehormatan profesi konsultan pajak, selain itu Robertus dan Hendro juga tidak melakukan tugas profesi dengan dedikasi tinggi dan independen. Pelanggaran kode etik yang menjurus pada pelanggaran pidana, juga terdapat pelanggaran kode etik lain yang tidak kalah penting yang seringkali diabaikan oleh konsultan pajak. Contohnya seperti terjadi perebutan klien antar konsultan pajak satu dengan konsultan pajak 
lainnya. Hal tersebut sebenarnya telah diatur secara jelas dalam AD/ART IKPI tentang Kode Etik Konsultan Pajak. Kode Etik Konsultan Pajak merupakan kaidah moral yang menjadi pedoman dalam berpikir, bersikap dan bertindak bagi setiap anggota IKPI. Kode etik ini seharusnya seorang konsultan pajak mampu mengikuti dan menjalankan aturan undang-undang pepajakan sehingga bisa membuat keputusan yang etis dan tidak merugikan Negara sendiri. Pernyataan tersebut didukung oleh Trevino (1986) yang menyatakan bahwa keputusan etis yang dibuat oleh konsultan pajak akan sangat tergantung pada faktor-faktor individual dari orang yang membuat keputusan, sehingga diperlukan penelitian yang lebih lanjut untuk mengkaji faktor-faktor yang dapat mempengaruhi pembuatan keputusan etis konsultan pajak, terutama faktorfaktor yang bersifat internal dari masing-masing individu. Faktor internal yang dapat mempengaruhi keputusan etis seseorang adalah kecerdasan intelektual, kecerdasan emosional, dan kecerdasan spiritual.

Menurut Amelia (2009) kecerdasan intelektual atau intelegensi merupakan kemampuan mental individu yang dapat dipergunakan untuk menyesuaikan diri di dalam lingkungan yang baru, serta dapat memecahkan masalah yang dihadapi dengan cepat dan tepat. Kecerdasan intelektual memiliki kemampuan menganalisis logika dan rasio seseorang. Kecerdasan intelektual berkaitan dengan keterampilan bicara, kecerdasan akan ruang, kesadaran akan sesuatu yang tampak, dan penguasaan matematika. Kecerdasan intelektual mengukur kecepatan kita untuk mempelajari hal-hal baru, memusatkan perhatian pada aneka tugas dan latihan, menyimpan dan mengingat kembali informasi objektif, terlibat dalam proses berpikir, bekerja dengan angka, berpikir abstrak dan analitis, serta memecahkan masalah dan menerapkan pengetahuan yang telah ada sebelumnya (Anastasi \& Urbina, 2007). Seseorang yang memiliki kecerdasan intelektual yang baik, maka mereka akan mampu memahami dan menjalankan tugasnya dengan sangat baik dan implikasinya kinerja mereka akan baik (Chrismastuti \& Purnamasari, 2004). Tugas yang dihadapi oleh seorang konsultan pajak merupakan suatu tugas yang menuntut konsultan pajak untuk memiliki pengetahuan, analisis, serta proses berpikir rasional yang digunakan untuk menarik sebuah keputusan bagi kliennya (Dwijayanti, 2009). Kecerdasan intelektual yang tinggi yang dimiliki seorang konsultan pajak akan dapat memberikan keputusan yang etis kepada kliennya.

Penelitian yang dilakukan oleh Uno, (2010:69), menjelaskan kecerdasan emosional merupakan serangkaian kemampuan, kompetensi, dan kecakapan nonkognitif yang memengaruhi kemampuan seseorang untuk berhasil mengatasi tuntutan dan tekanan lingkungan. Hal ini sependapat dengan penelitian Kusuma (2011) yang menyatakan seseorang dengan kecerdasan emosional yang berkembang dengan baik, kemungkinan besar akan berhasil dalam kehidupannya karena mampu menguasai kebiasaan berpikir yang mendorong produktivitas. Seorang konsultan pajak memerlukan kecerdasan emosional untuk membantu melakukan konsultasi maupun pemeriksaan guna mendeteksi kebenaran atas laporan perpajakan yang dilakukan klien (Melandy, 2007). Kecerdasan spiritual adalah kecerdasan untuk menghadapi dan memecahkan persoalan makna dan nilai yang menempatkan prilaku dan hidup manusia dalam konteks yang lebih luas yang memungkinkan seseorang untuk 
menyatukan hal-hal yang bersifat interpersonal dan intrapersonal serta menjembatani kesenjangan antara diri sendiri dan orang lain (Agustini \& Herawati, 2013). Pernyataan tersebut senada dengan Agoes \& Ardana (2009:19), yang menyatakan orang yang mempunyai kecerdasan spiritual tinggi sudah pasti mempunyai perilaku etis yang tinggi pula. Apabila auditor mempunyai SQ (budi) yang tepat, skandal dan manipulasi tindakan yang dilakukan oleh auditor tidak dapat terjadi. Profesi konsultan pajak dituntut integritas, dan kejujuran agar obyektif. Seorang konsultan bisa saja tidak jujur karena mendapat imbalan lebih dari klien, oleh karena itu kecerdasan spiritual merupakan landasan yang diperlukan untuk memfungsikan kecerdasan intelektual dan kecerdasan emosional secara efektif (Duska \& Duska, 2003).

Pengambilan keputusan etis tidak hanya dipengaruhi oleh faktor-faktor individu, tetapi juga oleh faktor-faktor situasional. Penelitian mengenai pengaruh faktor-faktor situasional terhadap pengambilan keputusan etis oleh konsultan pajak dilakukan oleh Killian \& Doyle (2004). Penelitian Killian \& Doyle (2004) ini menunjukkan bahwa faktor-faktor yang terbukti berpengaruh terhadap tingkat agresifitas penghindaran pajak oleh konsultan pajak adalah faktor-faktor situasional atau keadaan diluar individu tersebut. Faktor situasional yang berpengaruh terhadap keputusan etis adalah preferensi risiko, kekinian informasi, dan hubungan professional. Menurut penelitian Killian \& Doyle (2004) yang menyatakan bahwa Preferensi risiko adalah besar kecilnya risiko yang diambil oleh konsultan pajak dalam pengambilan keputusannya, jadi seorang pengambil keputusan yang cenderung enggan mengambil risiko akan menentukan sasaran dan alternatif yang berbeda dari apa yang dilakukan pengambil keputusan lain dalam situasi yang serupa. Kekinian Informasi berarti jika setiap pengambil keputusan selalu mendapatkan informasi terbaru mengenai sistem dan regulasi. Pengambil keputusan dapat memahami informasi tersebut sehingga pengetahuan dan pemahaman tentang perpajakan akan meningkat dan mampu mengambil keputusan yang etis. Hubungan professional dengan klien merupakan faktor yang berpengaruh terhadap pengambilan keputusan etis konsultan pajak dimana semakin dekat hubungan konsultan pajak dengan klien maka akan lebih cenderung untuk bersedia bertindak lebih jauh untuk kepentingan kliennya.

Penelitian-penelitian sebelumnya yang dilakukan oleh Amelia (2009) dan Swari \& Ramantha (2013) menunjukkan bahwa kinerja auditor dan pengambilan opini auditor dipengaruhi oleh faktor internal saja. Penelitian yang dilakukan oleh Killian \& Doyle (2004) dan Adriana et al. (2013) menunjukkan bahwa pengambilan keputusan etis konsultan pajak dipengaruhi oleh faktor situasional. Penelitian tersebut hanya meneliti faktor internal dan faktor situasional saja sehingga membuat peneliti termotivasi untuk melakukan penelitian kembali mengenai pengaruh kecerdasan intelektual, kecerdasan emosional, kecerdasan spiritual pada keputusan etis dengan menambahkan variabel bebas faktor situasional yaitu: preferensi risiko, kekinian informasi dan hubungan professional pada keputusan etis. Alasan peneliti menggunakan pengaruh faktor internal dan faktor situasional pada keputusan etis karena penelitian-penelitian tersebut belum menguji secara bersama-sama pengaruh faktor internal dan faktor situasional terhadap keputusan etis. Sehingga peneliti ingin melakukan 
pengembangan dari penelitian sebelumnya yaitu dengan menggabungkan faktor internal (dalam hal 3 Kecerdasan) dan faktor situasional serta meneliti pengaruh kedua faktor tersebut terhadap pengambilan keputusan etis. Hal ini didukung oleh Ludigdo (2007) menyatakan bahwa pengambilan keputusan etis tidak hanya dipengaruhi oleh faktor individu, tetapi juga faktor eksternal dari individu tersebut. Menurut penelitian Ludigdo (2007) yang menerangkan bahwa keberlangsungan praktik etika secara dinamis bukan hanya dari diri individu tetapi melibatkan dimensi eksternal dari diri individu. Jadi, peneliti menyimpulkan bahwa tindakan praktik etika merupakan interaksi antara faktor internal dari individu yang melakukan praktek etika tersebut dengan faktor eksternal (lingkungan) yang melingkupinya (Yuwono, 2011).

Perbedaan penelitian ini dibandingkan dengan penelitian sebelumnya adalah penggunaan objek yang berbeda dari penelitian sebelumnya. Penelitian sebelumnya yang meneliti faktor internal menggunakan auditor di Bali dan penelitian sebelumnya yang meneliti faktor situasional menggunakan konsultan pajak di luar Bali sedangkan penelitian ini menggunakan konsultan pajak yang terdaftar di IKPI cabang Bali. Alasan memilih konsultan pajak sebagai responden dalam penelitian ini karena beberapa penelitian sebelumnya lebih banyak menguji pembuatan keputusan etis auditor, baik auditor pemerintah seperti BPK, pemeriksa internal Bawasda maupun auditor independen, sedangkan sangat minim yang melakukan penelitian terhadap perilaku dari salah satu profesi penting dalam akuntansi, yaitu konsultan pajak. Faktor lain yang menjadi pertimbangan dipilihnya konsultan pajak terdaftar adalah budaya organisasi yang cenderung heterogen pada masing-masing konsultan pajak jika dibandingkan dengan auditor baik di pemerintahan maupun auditor independen. Auditor memiliki standar dalam melakukan audit, terutama standar pekerjaan lapangan, sedangkan standar tersebut tidak diatur secara jelas dalam profesi konsultan pajak. Alasannya juga memilih konsultan pajak di daerah Bali karena peneliti ingin meneliti apakah pengambilan keputusan etis konsultan pajak di Bali dipengaruhi oleh kedua faktor yaitu faktor internal (kecerdasan intelektual, kecerdasan emosional, dan kecerdasan spiritual) dan faktor situasional (preferensi risiko, kekinian informasi, dan hubungan professional). Berdasarkan penelitian sebelumnya peneliti tertarik untuk melakukan penelitian lebih lanjut mengenai konsultan pajak dengan judul Pengaruh Kecerdasan Intelektual, Kecerdasan Emosional, Kecerdasan Spiritual, dan Faktor Situasional pada Keputusan Etis Konsultan Pajak di Daerah Bali.

Salah satu faktor yang mendasari terbentuknya keyakinan perilaku, keyakinan normatif dan kontrol keyakinan menurut TPB adalah faktor individual. Salah satu komponen dari faktor individual adalah intelegence yang merujuk pada pengetahuan. Menurut Stren dalam Purwanto (2003), kecerdasan intelektual adalah kesanggupan untuk menyesuaikan diri kepada kebutuhan baru, dengan menggunakan alat-alat berpikir yang sesuai dengan tujuan. Menurut Yani (2011) menyatakan kecerdasan intelektual merupakan kecerdasan yang sangat dibutuhkan dalam keberhasilan seseorang. Kecerdasan intelektual tetap memengaruhi pola fikir seseorang karena kecerdasan intelektual merupakan kecerdasan pertama yang dikembangkan yang mampu membuat 
seseorang berfikir secara rasional untuk belajar dan memahami keputusan yang dibuatnya (Goleman, 2005).

Jika seseorang memiliki kecerdasan intelektual yang baik, maka mereka akan mampu memahami dan menjalankan tugasnya dengan sangat baik dan implikasinya kinerja mereka akan baik (Hughes \& Moizer, 2015). Tugas yang dihadapi oleh seorang konsultan pajak merupakan suatu tugas yang menuntut konsultan pajak untuk memiliki pengetahuan, analisis, serta proses berpikir rasional yang digunakan untuk menarik sebuah keputusan bagi kliennya. Kecerdasan intelektual yang tinggi yang dimiliki seorang konsultan pajak maka seorang konsultan pajak dapat memberikan keputusan yang etis kepada kliennya. Hal ini didukung oleh hasil penelitian Tikollah (2006), Lisda (2009), Choiriah (2013), Mahadewi (2015), Swari \& Ramantha (2013), dan Pratama (2017) menunjukkan bahwa kecerdasan intelektual berpengaruh positif terhadap keputusan etis. Berdasarkan uraian tersebut maka dapat ditarik suatu hipotesis:

$\mathrm{H}_{1}$ : Kecerdasan Intelektual berpengaruh positif pada keputusan etis konsultan pajak di Daerah Bali.

Berdasarkan TPB yang dikemukakan oleh Fishbein dan Ajzen awal tahun 1970-an, terdapat beberapa faktor yang mendasari terbentuknya keyakinan prilaku, keyakinan normative, dan kontrol keyakinan. Salah satu faktor yang mendasari adalah faktor individual yaitu emotion dan mood. Emotion dan mood merupakan komponen yang meliputi perasaan yang secara tidak langsung akan memengaruhi perilaku seseorang ketika menghadapi suatu keputusan. Rachmi (2010) mendefinisikan kecerdasan emosional sebagai komponen yang membuat seseorang menjadi pintar menggunakan emosinya. Emosi manusia berada di wilayah dari perasaan lubuk hati, naluri yang tersembunyi, dan sensasi emosi yang apabila diakui dan dihormati. Kecerdasan emosional akan menyediakan pemahaman yang lebih mendalam dan lebih utuh tentang diri sendiri dan orang lain.

Secara khusus konsultan pajak membutuhkan kecerdasan emosional yang tinggi karena dalam lingkungan kerjanya konsultan pajak akan berinteraksi dengan banyak orang baik di dalam maupun di luar lingkungan kerja (Sternberg, 2008). Kecerdasan emosional berperan penting dalam membentuk moral disiplin sebagai seorang konsultan pajak. Dalam dunia kerja konsultan pajak, berbagai masalah dan tantangan yang harus dihadapi seperti tuntutan tugas dan masalah hubungan dengan orang lain baik dengan klien maupun lainnya. Masalahmasalah tersebut bukanlah suatu hal yang hanya membutuhkan kemampuan intelektualnya, tetapi dalam menyelesaikan masalah tersebut, kemampuan emosi atau kecerdasan emosi lebih banyak diperlukan. Bila seorang konsultan pajak memiliki kecerdasan emosional yang tinggi maka keputusan dalam menghadapi masalahnya akan lebih baik. Hal ini didukung oleh hasil penelitian Tikollah (2006), Lisda (2009), Choiriah (2013), Mahadewi (2015), Swari \& Ramantha (2013), dan Pratama (2017) menunjukkan bahwa kecerdasan emosional berpengaruh positif terhadap keputusan etis. Berdasarkan uraian tersebut maka dapat ditarik suatu hipotesis:

$\mathrm{H}_{2}$ : Kecerdasan emosional berpengaruh positif pada keputusan etis konsultan pajak di Daerah Bali. 
Berdasarkan TPB yang dikemukan oleh Fishbein dan Ajzen awal tahun 1970-an menjelaskan bahwa religion merupakan faktor sosial yang dapat mempengaruhi keyakinan perilaku, keyakinan normatif, dan kontrol keyakinan. Religion erat kaitatnya dengan spiritual, dimana religion menempatkan perilaku dan hidup manusia dalam konteks makna yang lebih luas dan kaya sehingga memungkinkan seseorang untuk menyatukan hal-hal yang bersifat intrapersonal dan interpersonal, serta menjembatani kesenjangan antara diri dan orang lain (Zohar \& Marshall, 2007). Hal ini berarti orang yang memiliki kecerdasan spiritual akan mewujudkanya dalam perilaku yang luhur dan menjadi salah satu faktor yang mempengaruhi sikap dan perilaku etis seseorang (Idrus, 2002). Jadi, seorang dengan kecerdasan spiritual tinggi adalah orang yang memiliki prinsip dan visi yang kuat, mampu memaknai setiap sisi kehidupan serta mampu mengelola dan bertahan dalam kesulitan dan kesakitan. Dengan kata lain orang dengan kecerdasan spiritual tinggi dapat menghasilkan keputusan yang etis dalam menghadapi suatu masalah. Hal ini didukung oleh hasil penelitian Tikollah (2006), Lisda (2009), Choiriah (2013), Mahadewi (2015), Swari \& Ramantha (2013), dan Pratama (2017) menunjukkan bahwa kecerdasan spiritual berpengaruh positif terhadap keputusan etis. Berdasarkan uraian tersebut maka dapat ditarik suatu hipotesis:

$\mathrm{H}_{3}$ : Kecerdasan Spiritual berpengaruh positif pada keputusan etis konsultan pajak di Daerah Bali.

Teori etika dalam Falah (2006) menekankan pada prinsip moral dan perbuatan yang menjadi landasan bertindak seseorang sehingga apa yang dilakukannya dipandang oleh masyarakat sebagai perbuatan terpuji dan meningkatkan martabat serta kehormatan seseorang. Teori etika dalam Bertens (2000) menilai tentang apakah suatu prilaku sudah benar atau sudah sesuai dengan yang seharusnya dilakukan seperti tindakan mengambil risiko untuk menentukan keputusan yang akan dibuatnya. Dalam penelitian Gibson et al. (1985) menyatakan bahwa kecenderungan mengambil risiko adalah satu aspek yang mempengaruhi pengambilan keputusan. Seorang pengambil keputusan yang cenderung enggan mengambil risiko, akan menentukan sasaran yang berbeda, mengevaluasikan alternatif secara berbeda, dan menyeleksi alternatif yang berbeda dari apa yang akan dilakukan pengambil keputusan lain dalam situasi yang serupa (Jones \& Kavanagh, 1996). Individu yang enggan mengambil risiko akan berusaha melakukan pilihan yang kadar risiko atau ketidakpastiannya rendah, atau kadar kepastian tentang hasilnya tinggi (Drakulevski \& Taneva, 2015). Apabila konsultan pajak semakin berani menerima risiko, maka keputusan yang diambil akan cenderung tidak etis.

Hal ini didukung oleh penelitian yang dilakukan oleh Killian \& Doyle (2004) yang menyatakan bahwa terdapat perbedaan rekomendasi yang diberikan oleh konsultan pajak yang memiliki preferensi risiko tinggi dan rendah. Seorang konsultan pajak yang lebih berani untuk melanggar aturan-aturan perpajakan dan berani untuk menerima risikonya cenderung memberikan rekomendasi yang lebih agresif dalam penghindaran pajak. Preferensi risiko pada organisasi juga memberikan pengaruh terhadap pengambilan keputusan etis individu. Hal ini ditunjukkan oleh penelitian yang dilakukan oleh Wittmer (2010) yang menyatakan bahwa iklim lingkungan pekerjaan memberikan pengaruh positif 
terhadap pengambilan keputusan etis. Atmosfir dan cara melakukan segala sesuatu dalam organisasi akan mempengaruhi perilaku etis seorang individu. Jadi apabila organisasi semakin agresif dan berani menerima risiko, maka keputusan yang diambil oleh individu akan semakin tidak etis, dan sebaliknya. Hal ini juga didukung oleh penelitian yang dilakukan oleh Kusuma et al. (2016) yang menunjukkan bahwa preferensi risiko berpengaruh negatif terhadap pengambilan keputusan etis konsutan pajak. Berdasarkan uraian tersebut maka dapat ditarik suatu hipotesis:

$\mathrm{H}_{4}$ : Preferensi Risiko berpengaruh negatif terhadap pengambilan keputusan etis Konsultan Pajak di daerah Bali

Teori etika adalah kumpulan standar dari kode etik yang mengarahkan perilaku moral dan pengambilan keputusan etis (MacKewn \& VanVuren, 2008). Etika memberikan dasar bagi seseorang maupun sebuah komunitas dalam melakukan suatu tindakan. Jadi, dalam tindakan mengambil keputusan memerlukan dasar berupa informasi yang terbaru, karena informasi yang terbaru dapat menentukan keputusan yang tepat. Hal ini juga dinyatakan dalam Magro (2005) bahwa perolehan informasi adalah hal mendasar dalam pengambilan keputusan pajak. Informasi yang dimaksud disini adalah pemahaman mengenai aturan pajak terbaru dan penerapannya. Penelitian yang dilakukan oleh Bonner et al., (1992) sebagaimana dikutip oleh Magro (2005) menyatakan bahwa pemahaman informasi aturan perpajakan ini memberikan pengaruh positif dalam mengidentifikasi isu-isu perpajakan dan memberikan rekomendasi pajak. Penelitian lain mengenai pengaruh kekinian informasi terhadap pengambilan keputusan konsultan pajak dilakukan oleh Killian \& Doyle (2004), yang menyatakan bahwa kekinian informasi terbukti berpengaruh secara signifikan terhadap pengambilan keputusan etis oleh konsultan pajak. Konsultan pajak yang memiliki akses terhadap informasi perpajakan terbaru cenderung lebih tidak agresif dalam melakukan penghindaran pajak. Hal ini disebabkan karena semakin konsultan mengetahui peraturan-peraturan perpajakan terbaru, maka konsultan memahami risiko secara hukum, sehingga kecenderungan untuk berbuat tidak etis semakin rendah. Berdasarkan uraian tersebut maka dapat ditarik suatu hipotesis:

$\mathrm{H}_{5}$ : Kekinian Informasi memberikan pengaruh positif terhadap pengambilan keputusan etis Konsultan Pajak di daerah Bali

Teori etika dalam Robbins \& Judge (2002) menyatakan bahwa etika merupakan sebuah dasar untuk mengambil tindakan yang sesuai pada saat seorang individu atau kelompk menghadapi dilema moral. Dalam keadaan dilema moral ini yaitu hubungan profesional konsultan pajak dengan klien dalam hal mengambil keputusan. Hubungan profesional menjadi salah satu faktor yang terbukti berpengaruh terhadap pengambilan keputusan etis konsultan pajak. Penelitian yang dilakukan oleh Blanthorne et al. (2005) memberikan hasil bahwa tekanan dari klien akan memotivasi konsultan pajak untuk memberikan saran pajak yang agresif. Penelitian lain dilakukan oleh Killian \& Doyle (2004) menyatakan bahwa konsultan pajak yang lebih sering melakukan komunikasi dengan klien akan lebih cenderung untuk bersedia bertindak lebih jauh untuk kepentingan kliennya. Semakin intensif komunikasi dengan klien menyebabkan keberpihakan konsultan pajak kepada klien lebih 
besar, sehingga konsultan pajak akan cenderung untuk melaporkan penghasilan kliennya seminimal mungkin dengan cara-cara yang agresif. Berdasarkan uraian tersebut maka dapat ditarik suatu hipotesis:

$\mathrm{H}_{6}$ : Hubungan Profesional dengan klien berpengaruh negatif terhadap keputusan etis Konsultan Pajak di daerah Bali.

\section{METODE PENELITIAN}

Lokasi penelitian dilakukan di Kantor Konsultan Pajak di Daerah Bali sebagai representasi dari Kantor Konsultan Pajak di Indonesia, yang terdaftar di Ikatan Konsultan Pajak Indonesia (IKPI) tahun 2018 yang diperoleh melalui situs www.ikpi.or.id. Adapun daftar kantor konsultan pajak di Daerah Bali.

Populasi dalam penelitian ini adalah seluruh pegawai yang bekerja pada Kantor Konsultan Pajak di daerah Bali sebesar 498 orang. Penelitian ini menggunakan individu (konsultan pajak) sebagai unit analisis penelitian karena konsultan pajak berkaitan erat dengan objek penelitian ini, yaitu keputusan etis konsultan pajak. Etis tidaknya suatu keputusan yang dihasilkan sangat bergantung pada konsultan pajak sebagai pelaksana penerapan peraturan perpajakan yang berlaku dengan benar. Teknik penentuan sampel yang digunakan dalam penelitian ini adalah dengan teknik purposive sampling. Teknik analisis yang digunakan dalam penelitian adalah analisis regresi linier berganda (Sugiyono, 2016). Persamaan regresi pada penelitian ini adalah:

$$
Y=\alpha+b_{1} X_{1}+b_{2} X_{2}+b_{3} X_{3}+b_{4} X_{4}+b_{5} X_{5}+b_{6} X_{6}+\mathrm{e}
$$

Keterangan:

$\mathrm{Y} \quad=$ keputusan etis konsultan pajak

a $\quad=$ konstanta

$\mathrm{b}_{1} \quad=$ koefisien regresi variabel kecerdasan intelektual

$\mathrm{b}_{2} \quad=$ koefisien regresi variabel kecerdasan emosional

$b_{3} \quad=$ koefisien regresi variabel kecerdasan spiritual

$\mathrm{b}_{4} \quad=$ koefisien regresi variabel preferensi risiko

$\mathrm{b}_{5} \quad=$ koefisien regresi variabel kekinian informasi

$\mathrm{b}_{6} \quad=$ koefisien regresi variabel hubungan profesional

$\mathrm{X}_{1} \quad=$ kecerdasan intelektual

$\mathrm{X}_{2} \quad=$ kecerdasan emosional

$\mathrm{X}_{3} \quad=$ kecerdasan spiritual

$\mathrm{X}_{4} \quad=$ preferensi risiko

$X_{5} \quad=$ kekinian informasi

$\mathrm{X}_{6} \quad=$ hubungan profesional

$\mathrm{E}=$ error 


\section{HASIL DAN PEMBAHASAN}

Berdasarkan hasil olah data dengan bantuan SPSS, maka didapatkan hasil analisis regresi linier berganda seperti pada Tabel 1 berikut.

Tabel 1. Hasil Analisi Regresi Linier Berganda

\begin{tabular}{|c|c|c|c|c|c|}
\hline \multirow{2}{*}{ Variabel } & \multicolumn{2}{|c|}{$\begin{array}{l}\text { Unstandardized } \\
\text { Coefficients }\end{array}$} & \multirow{2}{*}{$\begin{array}{c}\begin{array}{c}\text { Standardized } \\
\text { Coefficients }\end{array} \\
\text { Beta }\end{array}$} & \multirow{2}{*}{$\mathrm{t}$} & \multirow{2}{*}{ Sig. } \\
\hline & B & $\begin{array}{c}\text { Std. } \\
\text { Error }\end{array}$ & & & \\
\hline (Constant) & 7,143 & 1,614 & & 4,426 & 0,000 \\
\hline Kecerdasan Intelektual $\left(\mathrm{X}_{1}\right)$ & 0,099 & 0,031 & 0,247 & 3,155 & 0,002 \\
\hline Kecerdasan Emosional (X2) & 0,031 & 0,013 & 0,185 & 2,304 & 0,024 \\
\hline Kecerdasan Spiritual (X3) & 0,052 & 0,018 & 0,234 & 2,878 & 0,005 \\
\hline Preferensi Risiko (X4) & $-0,204$ & 0,114 & $-0,120$ & $-1,797$ & 0,076 \\
\hline Kekinian Informasi (X5) & 0,060 & 0,129 & 0,026 & 0,464 & 0,644 \\
\hline Hubungan Profesional (X6) & $-0,376$ & 0,079 & $-0,299$ & $-4,761$ & 0,000 \\
\hline $\mathrm{R}$ & & & 0,907 & & \\
\hline$R$ Square & & & 0,822 & & \\
\hline Adjusted R Square & & & 0,807 & & \\
\hline F hitung & & & 55,460 & & \\
\hline Signifikansi F & & & 0,000 & & \\
\hline
\end{tabular}

Sumber: Data Penelitian, 2018

Berdasarkan Tabel 1 dapat disusun persamaan regresi sebagai berikut.

$$
\mathrm{Y}=7,143+0,099 \mathrm{X}_{1}+0,031 \mathrm{X}_{2}+0,052 \mathrm{X}_{3}-0,204 \mathrm{X}_{4}+0,060 \mathrm{X}_{5}-0,376 \mathrm{X}_{6}
$$

Nilai signifikasi uji $t$ sebesar 0,002 lebih kecil dari 0,05. Hal ini menunjukkan bahwa kecerdasan intelektual berpengaruh positif signifikan pada keputusan etis konsultan pajak ( $\mathrm{H}_{1}$ diterima).

Nilai signifikasi uji t sebesar 0,024 lebih kecil dari 0,05. Hal ini menunjukkan bahwa kecerdasan emosional berpengaruh positif signifikan pada keputusan etis konsultan pajak $\left(\mathrm{H}_{2}\right.$ diterima).

Nilai signifikasi uji t sebesar 0,005 sama dengan tingkat kesalahan 0,05. Hal ini menunjukkan bahwa kecerdasan spiritual berpengaruh positif signifikan pada keputusan etis konsultan pajak $\left(\mathrm{H}_{3}\right.$ diterima).

Nilai signifikasi uji $t$ sebesar 0,076 lebih besar dari 0,05. Hal ini menunjukkan bahwa preferensi risiko tidak berpengaruh signifikan pada keputusan etis konsultan pajak ( $\mathrm{H}_{4}$ ditolak).

Nilai signifikasi uji $t$ sebesar 0,644 lebih besar dari 0,05. Hal ini menunjukkan bahwa kekinian informasi tidak berpengaruh signifikan pada keputusan etis konsultan pajak ( $\mathrm{H}_{5}$ ditolak).

Nilai signifikasi uji $t$ sebesar 0,000 lebih kecil dari 0,05. Hal ini menunjukkan bahwa hubungan profesional berpengaruh negatif signifikan pada keputusan etis konsultan pajak $\left(\mathrm{H}_{6}\right.$ diterima).

Berdasarkan Tabel 1 menunjukkan bahwa nilai dari adjusted Rsquare adalah 0,807 atau 80,7 persen, memiliki arti bahwa variabel kecerdasan intelektual, kecerdasan emosional, kecerdasan spiritual, pereferensi risiko, kekinian informasi, dan hubungan profesional mampu mempengaruhi keputusan etis konsultan pajak di Daerah Bali sebesar 80,7\%. Sedangkan sisanya sebesar 19,3\% dipengaruhi oleh variabel lain yang tidak dimasukkan dalam penelitian ini. 
Berdasarkan Tabel 1 menunjukkan bahwa nilai $\mathrm{F}$ hitung sebesar 55,460 dengan tingkat signifikansi sebesar 0,000. Nilai tersebut lebih kecil dari $a=0,05$. Hal ini menunjukkan bahwa model persamaan dalam penelitian ini layak untuk digunakan.

Berdasarkan hasil penelitian menunjukkan bahwa hipotesis pertama $\left(\mathrm{H}_{1}\right)$ diterima yakni kecerdasan intelektual berpengaruh positif pada keputusan etis konsultan pajak di Daerah Bali. Hasil pengujian hipotesis ini konsisten dengan penelitian yang dilakukan oleh Tikollah (2006) yang menghasilkan bahwa kecerdasan intelektual berpengaruh positif terhadap sikap etis mahasiswa akuntansi. Sama dengan penelitian yang dilakukan oleh Lisda (2009) yang menyatakan bahwa kecerdasan intelektual berpengaruh positif terhadap perilaku etis auditor. Serta sama dengan penelitian yang dilakukan Choiriah (2013) yang menyatakan bahwa kecerdasan intelektual berpengaruh positif terhadap kinerja auditor. Penelitian ini juga mendukung Theory of Planned Behavior (TPB) yaitu faktor individual. Salah satu komponen dari faktor individual adalah intelegence yang merujuk pada pengetahuan. Teori ini menjelaskan bagaimana keinginan perilaku dalam hal intelegence yang memotivasi individu untuk terlibat dalam perilaku yang didefinisikan oleh sikap yang mempengaruhi perilaku dengan asumsi utama adalah individu rasional dalam mempertimbangkan tindakan mereka dan implikasi dari tindakan mereka. Jika seseorang memiliki kecerdasan intelektual yang baik, maka mereka akan mampu memahami dan menjalankan tugasnya dengan sangat baik dan implikasinya kinerja mereka akan baik sehingga dapat menarik suatu keputusan yang etis kepada kliennya.

Dengan kecerdasan intelektual, seorang konsultan pajak mampu memahami dan menjalankan tugasnya dengan sangat baik. Tugas yang dihadapi oleh seorang konsultan pajak merupakan suatu tugas yang menuntut konsultan pajak untuk memiliki pengetahuan, analisis, serta proses berpikir rasional yang digunakan untuk menarik sebuah keputusan bagi kliennya (Pasek, 2015). Jadi, Kecerdasan intelektual yang tinggi yang dimiliki seorang konsultan pajak maka seorang konsultan pajak dapat memberikan keputusan yang etis kepada kliennya, dengan demikian kecerdasan intelektual yang tinggi juga dapat mengarahkan seorang profesi konsultan pajak berperilaku etis dalam menghadapi permasalahan yang dihadapi dalam bekerja.

Berdasarkan hasil penelitian menunjukkan bahwa hipotesis kedua $\left(\mathrm{H}_{2}\right)$ diterima yakni kecerdasan emosional berpengaruh positif pada keputusan etis konsultan pajak di Daerah Bali. Hasil pengujian hipotesis ini mendukung penelitian yang dilakukan oleh Tikollah (2006) yang menghasilkan bahwa kecerdasan emosioanl berpengaruh positif terhadap sikap etis mahasiswa akuntansi. Sama juga dengan penelitian yang dilakukan oleh Lisda (2009) yang menyatakan bahwa kecerdasan emosional berpengaruh positif terhadap perilaku etis auditor. Serta sama dengan penelitian lainnya yaitu penelitian Choiriah (2013), Mahadewi (2015), Swari \& Ramantha (2013), dan Pratama (2017).

Penelitian ini juga mendukung Theory of Planned Behavior (TPB) yaitu faktor individual. Salah satu faktor yang mendasari faktor individual yaitu emotion dan mood. Emotion dan mood merupakan komponen yang meliputi perasaan yang secara tidak langsung akan mempengaruhi perilaku seseorang 
ketika menghadapi suatu keputusan. Kecerdasan emosinal yang dimiliki oleh seorang konsultan pajak akan membantunya memiliki rasa percaya diri untuk berbuat atau melakukan sesuatu tindakan yang positif, memiliki kemampuan untuk mengelola emosi dan desakan hati yang merusak, mampu memelihara norma integritas dan kejujuran serta sikap tanggung jawab yang tinggi atas kinerja pribadi, selain itu dapat membantu seorang konsultan pajak dalam menghadapi permasalahan yang dihadapi seperti tuntutan tugas dan masalah hubungan dengan orang lain baik dengan klien maupun lainnya, sehingga keputusan yang diambil oleh konsultan pajak akan menjadi etis (Southey, 2011).

Berdasarkan hasil penelitian menunjukkan bahwa hipotesis ketiga $\left(\mathrm{H}_{3}\right)$ diterima yakni kecerdasan spiritual berpengaruh positif pada keputusan etis konsultan pajak di Daerah Bali. Hasil pengujian hipotesis ini mendukung penelitian yang dilakukan oleh Tikollah (2006) yang menghasilkan bahwa kecerdasan spiritual berpengaruh positif terhadap sikap etis mahasiswa akuntansi. Sama dengan penelitian yang dilakukan oleh Lisda (2009) yang menyatakan bahwa kecerdasan spiritual berpengaruh positif terhadap perilaku etis auditor. Sertasama dengan penelitian lainnya yaitu penelitian Choiriah (2013), Mahadewi (2015), Swari \& Ramantha (2013), dan Pratama (2017).

Penelitian ini juga mendukung Theory of Planned Behavior (TPB) yaitu faktor individual. Salah satu faktor yang mendasari faktor individual yaitu religion. Orang yang memiliki kecerdasan spiritual akan mewujudkanya dalam perilaku yang luhur dan menjadi salah satu faktor yang mempengaruhi sikap dan perilaku etis seseorang (Rani \& Hamid, 2013). Seorang konsultan pajak yang memiliki kecerdasan spiritual akan mampu memaknai segala sesuatu yang dikerjakannya sebagai sebuah ibadah dan dia akan mampu mengontrol dirinya untuk tidak melakukan hal-hal yang negative (Abdurrahman \& Yuliani, 2011). Selain itu orang yang memiliki kecerdasan spiritual biasanya akan memiliki rasa tanggung jawab yang tinggi atas segala sesuatu yang dilakukannya (Agus, 2015). Sehingga seorang konsultan pajak yang memiliki kecerdasan spiritual akan mampu menerapkan keputusan etis pada dirinya (Achmad, 2014).

Berdasarkan hasil penelitian menunjukkan bahwa hipotesis keempat $\left(\mathrm{H}_{4}\right)$ ditolak yakni preferensi risiko tidak berpengaruh pada keputusan etis konsultan pajak di Daerah Bali. Hasil pengujian hipotesis ini tidak mendukung penelitian sebelumnya oleh Killian \& Doyle (2004) yang memberikan hasil bahwa terdapat perbedaan pengambilan keputusan etis antara konsultan pajak yang memiliki preferensi risiko tinggi dan rendah. Penelitian ini juga tidak mendukung penelitian yang dilakukan oleh (Kusuma et al., 2016), yang menyatakan bahwa kecenderungan mengambil risiko berpengaruh terhadap rekomendasi konsultan pajak.

Penelitian ini juga tidak mendukung teori etika yang menekankan prinsip moral pada individu yaitu menilai tipe individu dalam mengambil risiko untuk menentukan keputusan yang akan dibuatnya melainkan tidak melihat dari risiko klien. Perbedaan hasil penelitian ini dapat dijelaskan pada penelitian Kadous \& Magro (2001) yang dikutip oleh Adriana et al. (2013) yang menyatakan bahwa profesional pajak dalam hubungannya dengan risiko, tidak memberikan rekomendasi secara sama dan objektif untuk semua klien. Kadous \& Magro (2001) yang dikutip oleh Adriana et al. (2013) melakukan penelitian eksperimen 
untuk menguji perbedaan pengambilan keputusan oleh profesional pajak dengan adanya risiko berupa sangsi moneter dan non moneter untuk klien yang memiliki risiko tinggi dan rendah. Klien memiliki risiko tinggi apabila usaha klien tersebut sering terlibat dalam masalah hukum dan pengadilan, jenis usahanya termasuk dalam industri dengan risiko tinggi, menghadapi masalahmasalah organisasi serta keuangan, serta terlibat dalam transaksi yang mencurigakan (Roberts \& Klersey, 2012). Hasil penelitian menyatakan bahwa profesional pajak yang berhadapan dengan risiko pajak cenderung memberikan rekomendasi yang lebih agresif bila klien memiliki risiko yang rendah, dan sebaliknya memberikan rekomendasi yang lebih konservatif apabila klien memiliki risiko yang tinggi. Hal ini disebabkan karena pada klien dengan risiko tinggi akan semakin meningkatkan risiko profesional pajak untuk terkena sangsi moneter maupun non moneter apabila diketahui memberikan saran yang agresif, atau tidak sesuai dengan peraturan. Hal ini didukung dengan bukti empiris dari jawaban responden pada kuesioner yang diberikan, dimana cenderung lebih banyak responden kuesioner ini yaitu 57 responden yang dapat menerima risiko yang lebih rendah dan 49 responden tipe konservatif serta 52 responden yang tidak bersedia mengambil risiko yang lebih jauh apabila diminta oleh klien dari 79 responden yang sesuai dengan kriteria sampel. Hal ini yang menyebabkan preferensi risiko tidak berpengaruh secara signifikan pada keputusan etis konsultan pajak.

Berdasarkan hasil penelitian menunjukkan bahwa hipotesis kelima $\left(\mathrm{H}_{5}\right)$ ditolak yakni kekinian informasi tidak berpengaruh pada keputusan etis konsultan pajak di Daerah Bali. Pengujian hipotesis pada penelitian ini memberikan hasil yang bertentangan dengan penelitian Killian \& Doyle (2004) dan Magro (2005) tersebut. Penelitian ini menunjukkan bahwa kekinian informasi tidak berpengaruh terhadap pengambilan keputusan etis konsultan pajak. Hal ini didukung oleh Magro (2005) yang menjelaskan bahwa perolehan informasi adalah hal mendasar dalam pengambilan keputusan pajak, namun hal ini tidak dapat dibuktikan pada penelitian ini. Penelitian ini juga tidak mendukung teori etika dimana pengetahuan konsultan pajak itu tidak hanya pemahaman mengenai peraturan pajak terbaru, namun tidak dapat dipisahkan dari pengalaman yang dimiliki oleh konsultan pajak dan kerumitan situasi klien. Hasil yang bertentangan ini dapat dijelaskan oleh penelitian yang dilakukan oleh O'Donnell et al. (2005) yang dikutip Adriana et al. (2013). Berdasarkan penelitian O'Donnell et al. (2005) yang dikutip Adriana et al. (2013) melakukan penelitian mengenai hubungan antara pengetahuan (knowlegde), kerumitan situasi klien (task complexity) dengan rekomendasi yang diberikan oleh konsultan pajak. Menurut penelitian Adriana et al. (2013) yang menyatakan bahwa pada saat menerima perikatan dengan klien untuk mempersiapkan pelaporan pajak klien, profesional pajak perlu mengumpulkan informasi-informasi yang relevan mengenai klien mereka, mengidentifikasi aturan-aturan pajak yang ada, dan memberikan rekomendasi pelaporan pajak kepada klien. Hal ini juga didukung oleh penelitian yang dilakukan oleh Cloyd \& Spilker (1999) sebagaimana dikutip oleh Adriana et al. (2013) yang menyatakan bahwa profesional pajak perlu secara objektif mengevaluasi semua fakta relevan dan aturan pajak pada saat memberikan saran perpajakan. 
Pada proses pengambilan keputusan untuk pemberian rekomendasi kepada klien, perlu dievaluasi kesesuaian antara kondisi klien dengan aturan pajak yang ada, kemudian memutuskan pada pelaporan pajak klien, apakah sebuah beban tertentu sebaiknya diakui sebagai pengurang pajak atau apakah pendapatan tertentu sebaiknya diakui sebagai pendapatan menurut pajak. Menurut penelitian O'Donnell et al. (2005) yang dikutip Adriana et al. (2013) menyatakan bahwa profesional pajak dalam mengevaluasi informasi klien dan memberikan rekomendasi pelaporan pajak mengandalkan pemahamannya terhadap peraturan dan ketentuan pajak. Tujuannya adalah untuk merekomendasikan kepatuhan yang meminimalkan kewajiban pajak dalam batas yang diperbolehkan oleh aturan pajak. Pada saat situasi klien secara jelas sesuai dengan kriteria yang ditetapkan oleh aturan perpajakan, maka pemberian rekomendasi akan tampak jelas, dan pengambilan keputusan yang diambil relatif mudah. Namun, pada saat kesesuaian antara fakta klien dengan aturan pajak menjadi tidak jelas dan pengambilan keputusan menjadi semakin rumit, maka pada situasi ini, pemahaman dan pengetahuan mengenai keputusan tersebut memainkan peranan penting dalam proses pengambilan keputusan tersebut. Pada saat kerumitan meningkat, profesional perlu semakin bergantung pada pengalaman memberi rekomendasi kepatuhan pajak dengan kondisi yang mirip dengan kondisi tersebut.

Berdasarkan penelitian O'Donnell et al. (2005) yang dikutip oleh Adriana et al. (2013) tersebut dapat disimpulkan bahwa pengetahuan konsultan pajak itu tidak hanya pemahaman mengenai peraturan pajak terbaru, namun tidak dapat dipisahkan dari pengalaman yang dimiliki oleh konsultan pajak. Pengetahuan ini memberikan pengaruh terhadap pengambilan keputusan pada saat situasi yang dihadapi semakin rumit. Sedangkan apabila situasi yang dihadapi sederhana, maka pengetahuan tidak memberi pengaruh terhadap pengambilan keputusan. Hal ini didukung dengan bukti empiris dari kuesioner penelitian dimana kuesioner penelitian ini hanya menyatakan pengetahuan dengan ada tidaknya informasi terbaru yang dimiliki oleh konsultan pajak, tanpa melihat pengalaman dan kerumitan situasi klien. Hal ini menyebabkan tidak terbuktinya hipotesis mengenai hubungan antara informasi dengan pengambilan keputusan etis konsultan pajak.

Berdasarkan hasil penelitian menunjukkan bahwa hipotesis keenam $\left(\mathrm{H}_{6}\right)$ diterima yakni hubungan profesional berpengaruh negatif pada keputusan etis konsultan pajak di Daerah Bali. Hasil hipotesis pengujian ini mendukung penelitian yang dilakukan oleh Killian \& Doyle (2004) yang menyatakan bahwa terdapat perbedaan pengambilan keputusan etis antara professional pajak yang memiliki hubungan professional dekat dengan kliennya dan yang tidak. Hasil penelitian ini juga mendukung hasil penelitian Klepper \& Nagin (1989)sebagaimna dikutip oleh Blanthorne et al. (2005) yang memberikan hasil bahwa tekanan dari klien akan memotivasi konsultan pajak untuk memberikan saran pajak yang agresif.

Hal ini mendukung teori etika dimana untuk mengambil tindakan yang sesuai pada saat seorang individu atau kelompok menghadapi dilemma moral. Dalam keadaan dilemma moral ini yaitu hubungan professional konsultan pajak dengan klien dalam hal mengambil keputusan. Hubungan professional menjadi 
salah satu faktor yang terbukti berpengaruh terhadap pengambilan keputusan etis konsultan pajak. Konsultan pajak yang lebih sering melakukan komunikasi dengan klien akan lebih cenderung untuk bersedia bertindak lebih jauh untuk kepentingan kliennya. Semakin intensif komunikasi dengan klien menyebabkan keberpihakan konsultan pajak kepada klien lebih besar, sehingga konsultan pajak akan cenderung untuk melaporkan penghasilan kliennya seminimal mungkin dengan cara-cara yang agresif.

\section{SIMPULAN}

Kecerdasan intelektual berpengaruh positif pada keputusan etis konsultan pajak di Daerah Bali. Hasil ini berarti bahwa semakin tinggi kecerdasan intelektual yang dimiliki oleh seorang konsultan pajak di Daerah Bali, maka keputusan yang dibuatnya akan semakin etis.

Kecerdasan emosional berpengaruh positif pada keputusan etis konsultan pajak di Daerah Bali. Hasil ini berarti bahwa semakin tinggi kecerdasan emosional yang dimiliki oleh seorang konsultan pajak di Daerah Bali, maka keputusan yang dibuatnya akan semakin etis.

Kecerdasan spiritual berpengaruh positif pada keputusan etis konsultan pajak di Daerah Bali. Hasil ini berarti bahwa semakin tinggi kecerdasan spiritual yang dimiliki oleh seorang konsultan pajak di Daerah Bali, maka keputusan yang dibuatnya akan semakin etis.

Preferensi Risiko tidak berpengaruh secara signifikan pada keputusan etis konsultan pajak di Daerah Bali. Hasil ini berarti bahwa semakin tinggi atau semakin rendah preferensi risiko yang dimiliki oleh seorang konsultan pajak di Dearah Bali, maka tidak berpengaruh secara signifikan terhadap keputusan yang akan dibuatnya.

Kekinian informasi tidak berpengaruh secara signifikan pada keputusan etis konsultan pajak di Daerah Bali. Hasil ini berarti bahwa semakin tinggi atau rendah kekinian informasi yang didapat oleh seorang konsultan pajak di Daerah Bali, maka tidak berpengaruh secara signifikan terhadap keputusan yang akan dibuatnya.

Hubungan professional berpengaruh negatife pada keputusan etis konsultan pajak di Daerah Bali. Hasil ini berarti bahwa semakin tinggi hubungan professional maka keputusan yang akan dibuatnya semakin tidak etis.

\section{REFERENSI}

Abdurrahman, \& Yuliani. (2011). Determinasi Pengambilan Keputusan Etis Auditor Internal (Studi Empiris pada BUMN dai Magelang dan Temanggung). Widya Warta, 2.

Achmad, T. (2014). Menjadikan Konsultan Pajak sebagai Agents of Tax Compliance.

Adriana, P. R., \& Baridwan, Z. (2017). Determinan Pembuat Keputusan Etis Konsultan Pajak. Tesis. Universitas Brawijaya.

Adriana, P., Rosidi, \& Baridswan, Z. (2013). Faktur Individu Dan Factor Situasional: Determinan Pembuatan Keputusan Etis Konsultan Pajak. Jurnal Akuntansi El-Muhasaba, 4(2), 1-24. https:/ / doi.org/10.18860/em.v4i2.2456

Agoes, S., \& Ardana, I. C. (2009). Etika Bisnis dan Profesi: Tantangan Membangun 
Manusia Seutuhnya. Jakarta: Salemba Empat.

Agus, S. (2015). Pengaruh Idealisme, Komitmen Profesional dan Skeptisme Profesional

Pada Pembuatan Keputusan Etis Konsultan Pajak di Provinsi Bali. Universitas Udayana.

Agustini, S., \& Herawati, N. T. (2013). Pengaruh Kecerdasan Intelektual, Kecerdasan Emosional, dan Kecerdasan Spiritual terhadap Sikap Etis Mahasiswa S1 Akuntansi Universitas Pendidikan Ganesha Singaraja. Jurnal Ilmiah Mahasiswa Akuntansi Undiksha, 1(1).

Amelia, M. (2009). Pengaruh Kecerdasan Emosional dan Kecerdasan Intelegensi terhadap Kinerja Auditor Eksternal dengan Kepercayaan Diri sebagai Variabel Moderating pada KAP DKI Jakarta. Universitas Islam Negeri Syarif Hidayatullah.

Anastasi, A., \& Urbina. (2007). Tes Psikologi (Terjemahan). Jakarta: PT Indeks.

Aryo Putranto Saptohutomo. (2013). Suap Petugas Pajak Dirut PT Mutiara Virgo

$\begin{array}{llll}\text { Dipenjara } & 2 & \text { Tahun. } & \text { Retrieved }\end{array}$ https://www.merdeka.com/peristiwa/suap-petugas-pajak-dirut-ptmutiara-virgo-dipenjara-2-tahun.html

BeritaSatu. (2011). Robertus Dituntut Empat Tahun Penjara. Retrieved from https:// www.beritasatu.com/hukum/7863-robertus-dituntut-empat-tahunpenjara.html

Bertens, K. (2000). Pengantar Etika Bisnis. Yogyakarta: Kanisius.

Bonner, JJ., Heyward, S., \& Fackenthal, DL. (1992). Temperature-dependent regulation of a heterologous transcriptional activation domain fused to yeast heat shock transcription factor. Mol Cell Biol 12(3):1021-30.

Blanthorne, Burton, \& Fisher. (2005). The Aggressiveness of Tax Professional Reporting: Examining the Influence of Moral Reasoning. Working Paper Series College of Business Administration University of Rhode Island.

Budileksmana, A. (2001). Pemeriksaan Pajak Sebagai Upaya Untuk Mendorong Kepatuhan Wajib Pajak. Jurnal Akuntansi Dan Investasi, 2(1), 56-74.

Choiriah, A. (2013). Pengaruh Kecerdasan Emosional, Kecerdasan Intelektual, Kecerdasan Spiritual Dan Etika Profesi Terhadap Kinerja Auditor Dalam Kantor Akuntan Publik. Jurnal Akuntansi, 1(1).

Chrismastuti, A. A., \& Purnamasari, V. (2004). Hubungan Sifat Machiavellian, Pembelajaran Etika dalam Mata Kuliah Etika, dan Sikap Etis Akuntan: Suatu Analisis Perilaku Etis Akuntan dan Mahasiswa Akuntansi di Semarang. Proceeding Simposium Nasional Akuntansi VII, 2(3), 247-266.

Cloyd, C.B. \& Spilker D.C. (1999) The Influence of Client Preferences on Tax Professionals' Search for Judicial Precedents, Subsequent Judgments and Recommendations. The Accounting Review: July 1999,Vol.74,No.3, pp.299322.

Devos, K. (2012). The impact of tax professionals upon the compliance behavior of Australian individual taxpayers. Revenue Law Journal, 22(1), 1-26.

Drakulevski, L., \& Taneva, A. (2015). The Influence of Spiritual Intelligence on Ethical Behavior in Macedonian Organization. 2nd International Symposium.

Duska, R. F., \& Duska, B. S. (2003). Accounting Ethics. United Kingdom: Blackwell Publishing Ltd. 
Dwijayanti, A. P. (2009). Pengaruh Kecerdasan Emosional, Kecerdasan Intelektual, Kecerdasan Spiritual, dan Kecerdasan Sosial Terhadap Tingkat Pemahaman Akuntansi. Universitas Pembangunan Nasional "Veteran."

Falah, S. (2006). Pengaruh Budaya Etis Organisasi dan Orietasi Etis terhadap Sensitivitas Etis. Universitas Diponegoro.

Gibson, Ivancevich, \& Donelly. (1985). Organisasi. Jakarta: Erlangga.

Goleman, D. (2005). Kecerdasan Emosi: Mengapa Emotional Intelligence Lebih Tinggi Daripada IQ. (T. Hermay, Ed.). Jakarta: PT. Gramedia Pustaka Utama.

Harmana, I. M. D., Wirakusuma, M. G., \& Wirama, D. G. (2017). Pengaruh Idealisme, Pengalaman, dan Komitmen Profesional pada Pembuatan Keputusan Etis Konsultan Pajka terdaftar di Wilayah Bali-Nusa Tenggara. E-Jurnal Ekonomi Dan Bisnis Universitas Udayana, 6(10), 3549-3578.

Hughes, F. J., \& Moizer, P. (2015). Assessing the quality of services provided by UK tax practitioners. EJournal of Tax Research, 13(1), 51-75.

Idrus, M. (2002). Kecerdasan Spiritual Mahasiswa Yogyakarta, Psikologi Phronesis. Jurnal Ilmiah Dan Terapan, 4(8).

Jones, G. E., \& Kavanagh, M. J. (1996). An Experimental Examination of The Effects of Individual and Situational Factors on Unethical Behavioral Intentions in The Workplace. Journal of Business Ethics, 15(5), 511-523.

Kadous, K., \& Magro, A. (2001). The Effects of Exposure to Practice Risk on Tax Professionals' Judgements and Recommendations. Contemporary Accounting Research; Fall 2001, 18(3), 451.

Killian, S., \& Doyle, E. (2004). Tax Aggression among Tax Professionals: The Case of South Africa. Journal of Accounting, Ethics \& Public Policy, 4(3).

Klepper, S, D. Nagin. 1989. The deterrent effect of perceived certainty and severity of punishment revisited. Criminology 27(4) 721-746.

Kusuma, H. S. (2011). Pengaruh Pelaksanaan Etika Profesi dan Kecerdasan Emosional Terhadap Pengambilan Keputusan Bagi Auditor (Studi Empiris pada Kantor Akuntan Publik dan Badan Pemeriksa Keuangan di Semarang). Universitas Diponegoro.

Kusuma, T. H., Utami, H. N., \& Ruhana, I. (2016). Pengaruh Persepsi Peran Etika dan Tanggung Jawab Sosial, Sifat Machiavellian, dan Preferensi Risiko Terhadap Pengambilan Keputusan Etis (Studi pada Konsultan Pajak di Kota Malang). Jurnal Perpajakan (JEJAK), 10(1), 1-10.

Lisda, A. (2009). Pengaruh Kemampuan Intelektual, Kecerdasan Emosional dan Kecerdasan Spiritual Terhadap Perilaku Etis Auditor Serta Dampaknya Pada Kinerja. Universitas Islam Negeri Syarif.

Ludigdo, U. (2007). Paradoks Etika Akuntan. Yogyakarta: Pustaka Pelajar.

MacKewn, A., \& VanVuren, K. (2008). Business Training, Reasoning Skills, and Philosophical Orientation: Correlates of Ethical Decision-Making. International Journal of Management and Marketing Research, 1(1).

Magro, A. M. (2005). Knowledge, Adaptivity, and Performance in Tax Research. The Accounting Review, 80(2), 703-722.

Mahadewi, L. (2015). Pengaruh Intelligence Quotient (iq), dan Emotional Spiritual Quotients (esq) Terhadap Perilaku Etis Profesi Akuntan Publik dengan Locus of Control Sebagai Variabel Moderasi (studi empiris pada kantor akuntan publik di wilayah bali). E-Journal Akuntansi, 3(1). 
Melandy, R. (2007). Sinkronisasi Komponen Kecerdasan Emosional Dan Pengaruhnya Terhadap TingkatPemahaman Akuntansi Dalam Sistem Pendidikan Tinggi Akuntansi. Simposium Nasional Akuntansi X.

O'Donnell, E., Koch, B., \& Boone, J. (2005). The influence of domain knowledge and task complexity on tax professionals' compliance recommendations. Accounting, Organizations and Society, 30(2), 145-165.

Pasek, S. (2015). Pengaruh Kecerdasan Intelektual Pada Pemahaman Akuntansi Dengan Kecerdasan Emosi dan Kecerdasan Spiritual Sebagai Variabel Pemoderasi. Universitas Udayana.

Pratama, I. (2017). Pengaruh Kecerdasan Intelektual, Kecerdasan Emosional, Kecerdasan Spiritual, Pada Keputusan Etis Konsultan Pajak Di Daerah Bali Dengan Locus Of Control Sebagai Variabel Moderasi. Universitas Udayana.

Pratama, I. M. I., \& Wirama, D. G. (2018). Locus Of Control Pemoderasi Pengaruh Kecerdasan Intelektual, Emosional, dan Spiritual Pada Keputusan Etis Konsultan Pajak. E-Jurnal Akuntansi Universitas Udayana, 22(1), 595-624. https:// doi.org/10.24843/EJA.2018.v22.i01.p23

Purwanto, N. (2003). Psikologi Pendidikan. Bandung: PT. Remaja Rosdakarya.

Rachmi, F. (2010). Pengaruh Kecerdasan Emosional, Kecerdasan Spiritual, dan Perilaku Belajar Terhadap Pemahaman Akuntansi. Jurnal Pendidikan AkuntansiJurnal Pendidikan Akuntansi.

Rani, A.A., A., \& Hamid, M. R. (2013). The Impact of Spiritual Intelligence on Work Performance: case Studies in Government hospitals of East Cost Malaysia. The Macrotheme Review, 2, 46-52.

Robbins, S. P., \& Judge. (2002). Perilaku Organisasi. Jakarta: Salemba Empat.

Roberts, M. L., \& Klersey, G. F. (2012). Effects of Experience on Tax Professionals' Evaluations of Facts and Judgments. American Taxation Association Midyear Meeting: Research-In-Process.

Southey, G. (2011). The Theories of Reasoned Action and Planned Behaviour Applied to Bussiness Decions: A Selective Annolated Bibligraphy. Journal of New Bussiness Ideas \& Trenas, 9, 43-50.

Sternberg, J. R. (2008). Psikologi Kognitif. Yogyakarta: Pustaka Pelajar.

Sutanto, L., \& Tjondro, E. (2013). Preferensi Wajib Pajak Terhadap Konsultan Pajak dalam Memilih Konsultan Pajak: Honest Consultant, Creative Consultant, dan Cautious Consultant. Tax \& Accounting Review, 3(2), 1-14.

Swari, I. A. P. C. M., \& Ramantha, I. W. (2013). Pengaruh Independensi dan Tiga Kecerdasan terhadap Pertimbangan Pemberian Opini Auditor. E-Jurnal Akuntansi Universitas Udayana, 4(3), 489-508.

Tikollah. (2006). Pengaruh Kecerdasan Intelektual, Emosional, dan Kecerdasan Spiritual Terhadap Sikap Etis Mahasiswa Akuntansi (Studi Pada Perguruan Tinggi Negeri di Kota Makassar Provinsi Sulawesi Selatan). Simposium Nasional Akuntansi IX Padang.

Trevino, L. K. (1986). Ethical Decision Making in Organizations: A PersonSituation Interactionist Model. Academy of Management Review, 11(3), 601617.

Uno, H. B. (2010). Orientasi Baru Dalam Psikologi Pembelajaran. Jakarta: PT Bumi Aksara.

Wittmer, D. (2010). Good Business: Exercising Effective and Ethical Leadership. 
Retrieved from www. enterpriseethics.org.dnnmax.com

Yani, F. (2011). Pengaruh Kecerdasan Intelektual, Kecerdasan Emosional, Kecerdasan Spiritual Terhadap Pemahaman Akuntansi. Jurnal Akuntansi Pendidikan.

Yuwono, I. D. (2011). Memahami Berbagai Etika Profesi E Pekerjaan. Yogyakarta: Pustaka Yustisia.

Zohar, D., \& Marshall. (2007). SQ: Memanfaatkan Kecerdasan Spiritual Dalam Berpikir Integralistik dan Holistik Untuk Memaknai Kehidupan" Cetakan II. (R. Astuti, Ahmad Najib Burhani, \& A. Baiquni, Eds.). Bandung: Mizan. 